\title{
MODELLING OF COMPONENTS OF HYBRID AND CITY TRANSPORTATION IN SHAREWARE SOFT
}

D.V. Topolsky ${ }^{1}$, topol69@mail.ru,

E.V. Solomin ${ }^{1}$, nii-uralmet@mail.ru,

I.G. Topolskaya ${ }^{1}$, irina_topol71@mail.ru,

N.D. Topolsky ${ }^{1}$, ntopolsky@mail.ru.

${ }^{1}$ South Ural State University, Chelyabinsk, Russian Federation.

\begin{abstract}
Under the project of "The development of scientific-technical solutions in components of mobile charging devices for accumulating batteries of hybrid and electric drives of heavy and passenger city automobile transportation" the group of scientists develop the mathematic models of LiFePo4 lithium-ion batteries to study, check and confirm the algorithms predicted prior to get the most efficient rapid charge with no damage to the battery and shortage of life time. The usage of shareware (freeware) software essentially speeds up the works as the students and postgraduates may use such software without any limitation because of no license. Since lithium-ion batteries become more and more popular worldwide recently, it is a significant scientific and technical scope. The project is aimed on the development of the system of rapid charge which would be economically feasible for the new hybrid "KAMAZ" trucks, and the topic should be prospective for the development of the next research and design projects with the development of special charging equipment both for heavy load and commercial city transportation.
\end{abstract}

Keywords: lithium-ion battery; city transportation; mathematical modelling; simulation; shareware freeware software.

\section{Introduction}

One of the modern areas for development of transportation vehicles is the invention of heavy load and city transportation on the base of electric traction. This type of engines doesn't require any uninterrupted electric power supply in the form of accumulating batteries.

The wide usage of accumulating batteries in residential cars and commercial heavy and city transportation had leaded to another problems like the rational and efficient approaches of charging such a batteries, which in turn should be solved as soon as possible. The task of the design and development of electric transportation vehicles was announces, and being solved. The vehicles should compete with the traditional transportation in both technical and cost indicators. The problem of efficient charge becomes highly pointed due to the development of electric transportation vehicle market.

\section{Hybrids and Fully Electricals}

Hybrid electric transportation vehicles use more than one energy source for the front wheel drive [1]. As a rule the design of hybrid transportation requires the usage of both internal combustion engine and electric motor. Today the modern complete and moderate power engines use the parallel as well as series design architecture. In parallel circuitry 
the electric motor and internal combustion engine start almost simultaneously, and in series - the internal combustion engine with the help of alternator, provides the extra supply of energy for electric motor. The most of hybrid vehicles are the full hybrids as both the electric motor and internal combustion engine may operate also simultaneously. The moderate hybrids are different from the full hybrids by the operation of electric motor. Here the electric motor plays an auxiliary role of extra traction power during the start or a device for accumulating extra charge in batteries during the braking mode. The hybrid electric transportation vehicles are promising as a heavy and city commercial transportation. However they also need a special stations for charging the accumulating batteries.

\section{Approaches of Modelling}

There are several different approaches and modes of accumulating batteries charge today [2]. All charging devices should provide the most optimal mode of charge from the beginning to the end of charging process. Thus the charging devices provide and automatically change the voltage and current values depending on the stage of charging process [3].

The direct current is supported on the direct current mode for the whole stage of charge. The advantage of this approach is relatively small time of charge, however the ageing of battery becomes more rapid because of high current loading on the final stage of charge, and the life time of battery decreases.

If the charging process will be controlled by direct current constant voltage, then the process of final stage will be essentially slower and the time of charge will be increased.

And finally the third combine mode type. This is the two previous in one. First the charge by direct current constant current finalizing by the stabilized voltage. This is the most optimal but the most complex approach because of the pulse chart sequence [4].

Though surely could be stated that all modern charging devices operate as described in combine approach. And use the different speed of charge. The speed of charge is in proportion to the force of current flowing via accumulating battery. However we should note that increasing the charging current, not only the speed of charge will be higher but also the ageing speed. However the cases are very different. For instance the automobile accumulating battery is expensive and it should be charged by nominal current.

The figure 1 represents the different modes of battery usage [5].

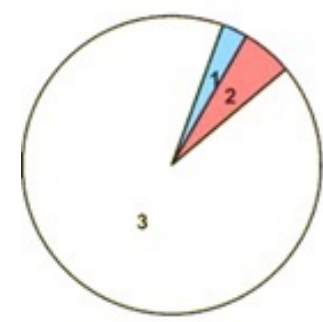

a)

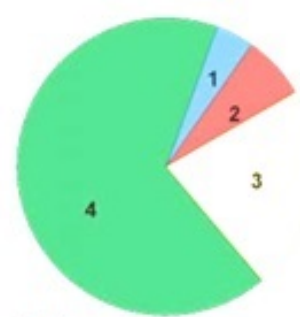

b)

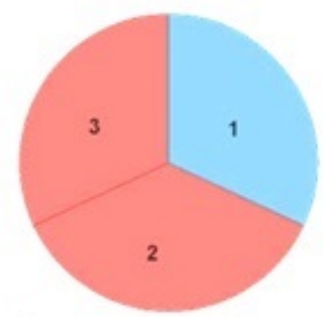

c)

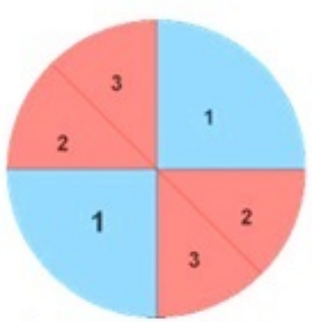

d)

Fig. 1. Modes of accumulating battery usage: a) - stationary batteries, b) - starter batteries, c) - tracking batteries (normal duty), d) - traction batteries (intensive mode), 1 - discharge, 2 charge, 3 - extra charge, 4 - idling 
Traction batteries are mostly used in the full "charge-discharge" cycle. The manufacturers of such batteries guarantee 1,200-1,500 cycles during the life time. However for that the end user should meet all the strong requirements for their usage and charging modes.

Thereby the research of accumulating batteries for the vehicles and commercial heavy and city transportation, and the development of charging devices for such vehicles, is the priority area of applied science and technology in Russian Federation [6].

The group of authors takes part in the applied scientific-technical research and development project "The development of scientific-technical solutions in components of mobile charging devices for accumulating batteries of hybrid and electric drives of heavy and passenger city automobile transportation" under the Government Federal Call "Research and development in higher-priority areas of Russian Federation ScientificTechnology Complex on Years 2014-2020". The chief company in charge of the project is Federal State Budget Educational Enterprise of High Professional Education "South Ural State University" (National Research University). The Industrial Partner is "KAMAZ" Joint Stock Company.

\section{Project Goal}

The goal of the project is the development of domestic component base for the mobile (on board) and stationary devices providing rapid charge of accumulating batteries and on-board net electric supply during the driving and parking, under the global project "Development of next-generation "KAMAZ" trucks up to Year 2020".

The project is aimed on the development of the system of rapid charge which would be economically feasible for the new hybrid "KAMAZ" trucks, and the topic should be prospective for the development of the next research and design projects with the development of special charging equipment both for heavy load and commercial city transportation.

In case the project will have a success, the profile of Industrial Partner allows the forecasting of "KAMAZ", JSC production spectrum expansion from the heavy load transportation vehicles up to electric transportation of wide range.

The main scientific and engineering tasks of the project:

- development and study of mathematic models of accumulating batteries with rapid charge control systems;

- development of rapid charge algorithms with automatic determination of grid power and diagnostic algorithms providing the safe long term use of traction accumulating batteries for electric transportation vehicles;

- development of circuitry and design of mobile and stationary reversible voltage converter with the function of inverter for on-board and external devices alternating current power supply;

- development of control system for charging converter with the information exchange by CAN bus.

The efficient solution of the tasks is closely connected with the adjustment of mathematic model of accumulating battery. In the project the adjustment of mathematic model of accumulating battery is solved as follows: 
- we build a system of equations of accumulating battery on the base of equivalent substitution electric circuit [7];

- we develop the algorithm of rapid charge with the automatic determination of grid power;

- we develop the algorithm of calculation of the obtained mathematic model.

The research of using a different batteries for hybrid transportation had shown the advantages of LiFePO4 (Lithium-Ferrum-Phosphate) batteries [8]. Their usage instead of traditional lead-acid batteries allows reducing the self price of electric consumption on up to 20 (17 average). It is known that this type of lithium-ion battery uses the LiFePO4 as a cathode, which provides longer life time than the other lithium-ion batteries types. Due to the DC voltage $3.2 \mathrm{~V}$ on output, the four batteries could be connected in series to get the nominal voltage of $12.8 \mathrm{~V}$. This is closed to the standard voltage of lead-acid batteries with six elements. Due to the excellent safety parameters the LFP batteries become very good potential substitute of lead-acid accumulating batteries in automobile industry. As nickel accumulating batteries the LiFePO4 batteries have a stable DC voltage (which is different from the other Li-ion batteries). The output voltage is closed to $3.2 \mathrm{~V}$ during discharge until the charge will not be exhausted in full. This may essentially simplify or even eliminate the control of voltage in the chains.

In modeling of the battery it is suitable to preset it with the approximate electric substitute circuit which reflects the main processes in it as in element of electric chain. To build the equations connecting the parameters of mathematic model, we used the equivalent electric substitute circuit (Fig. 2). It represents a set of active and re-active elements connected between each other. Each of the elements imitates physic-chemical parameter of the studied accumulating battery.

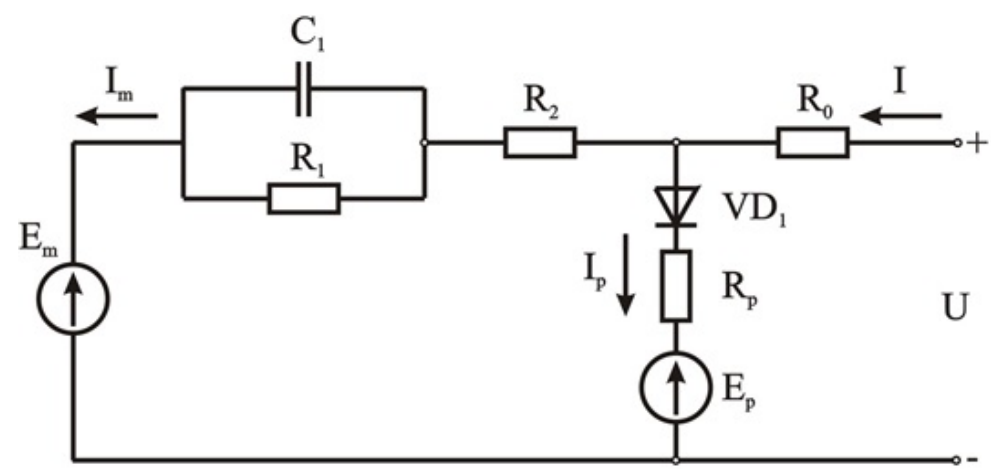

Fig. 2. Equivalent electric substitute circuit of accumulating battery

Equation system could be presented as follows:

$$
\begin{aligned}
& E_{m}=E_{m 0}-K_{E} \cdot(273+\Theta) \cdot(1-S O C), \\
& R_{1}=-R_{10} \cdot \ln (D O C), \\
& C_{1}=\frac{\tau_{1}}{R_{1}} \\
& R_{2}=R_{20} \cdot\left(e^{\left(A_{21}(1-S O C)\right)} /\left(1+e^{\left(A_{22} \frac{I_{m}}{I^{*}}\right)}\right)\right),
\end{aligned}
$$




$$
\begin{aligned}
& I_{p}=V_{p n} \cdot G_{p o} \cdot e^{\left(\frac{V_{p n} /\left(\tau_{p} \cdot s+1\right)}{V_{p o}}+A_{p} \cdot\left(1-\frac{\Theta}{\Theta_{f}}\right)\right),} \\
& Q_{e}(t)=Q_{e_{-} i n i t}+\int_{0}^{t}-I_{m}(\tau) d \tau \\
& C(I, \Theta)=\frac{K_{c} \cdot C_{0^{*}} \cdot K_{t}}{1+\left(K_{c}-1\right) \cdot\left(I / I^{*}\right)^{\delta}}, \\
& S O C=1-\frac{Q_{e}}{C(0, \Theta)}, \\
& D O C=1-\frac{Q_{e}}{C\left(I_{\text {avg }}, \Theta\right)}, \\
& I_{\text {avg }}=\frac{I_{m}}{\tau_{p} \cdot s+1}, \\
& \Theta(t)=\Theta_{\text {init }}+\int_{0}^{t}\left(\left(P_{s}-\frac{\Theta-\Theta_{a}}{R_{\Theta}}\right) / C_{\Theta}\right) d \tau, \\
& P_{s}=\frac{V_{R_{1}}^{2}}{R_{1}}+I^{2} \cdot R_{0}+I^{2} \cdot R_{2}, \\
& R_{0}=R_{00} \cdot\left(1+A_{0} \cdot(1-S O C)\right) .
\end{aligned}
$$

The calculation of equations could be solved by numerical methods. The base of the numerical method is the approach of numerical integration - method of iterations and trapezium. The source data of mathematical model are numerical analytic description of basic resistances $R_{1}$ and $R_{2}$, and capacity $C_{1}$ of main branch, resistance on terminals of one element of the battery $R_{0}$, current value of main branch $I_{m}$, condition of capacity of the battery $\mathrm{C}(\mathrm{I}, \theta)$, current value in spurious chain $I_{p}$ and power losses $P_{s}$ taking into account the constant $E_{m 0}$ - voltage of idling at full charge, $R_{00}$ - resistance $R_{0}$ at fully charged battery (State of Charge, $\mathrm{SOC}=1$ ),$R_{10}$ - resistance $R_{1}$ at battery full charge depth (DOC $=1), R_{20}$ - resistance $R_{2}$ in normal conditions, $V_{p m}$ - voltage on parasitic chain and $G_{p o}, A_{p}, A_{21}, 22$ - constants taken from Technical Data for specific battery. The unknown values are the internal electromotive force $E_{m}$, level of battery charge $Q_{e}$ and temperature of electrolyte in battery $\theta$, to be obtained numerically as a function of time. The built model allows the researching of dependence of internal electromotive force on the battery charge level.

Lithium-ion battery has a very clear charging requirements in limitation of temperature and overcharge. The battery should be charged by DC current imitating the current level to prevent the overheating on the early stage of charging process. Then the main requirement for Charging Device will be the monitoring of voltage on each in-series connected element of battery to keep the balance and identical voltage on each element. Thus the Charging Device should contain the circuits of appropriate protection.

\section{Algorithm}

The proposed algorithm (Fig. 3) OF Lithium-ion battery is as follows:

- Measure the initial idling voltage $U_{0}$ of each element of the battery. 
- If the voltage value of element is $2.9 \mathrm{~V}<U_{0}<4.2 \mathrm{~V}$ - then discharge the battery by current $2.8 \mathrm{C}(\mathrm{A})$ up to the upper level $(4.2 \mathrm{~V})$ or up to timer switch off (in accordance with the passport of device).

- Charge the battery by constant DC voltage up to current reduction less than the threshold value or up to timer switch off.

To get the adequate modelling results it is necessary to take into account the software which the calculation of the proposed mathematic model will be calculated in. Mathematical packages are widely distributed on the market in the form of the systems of computer mathematics - Matlab, Mathcad, Maple, Mathematica, etc. All of them have a wide capabilities, advantages and disadvantages. However when the students and postgraduates are involved into the research process the big disadvantage of these packages is the necessity of purchasing the license, which limits the scientific research very often. Thus the usage of the shareware software and makes these research more innovative [9].

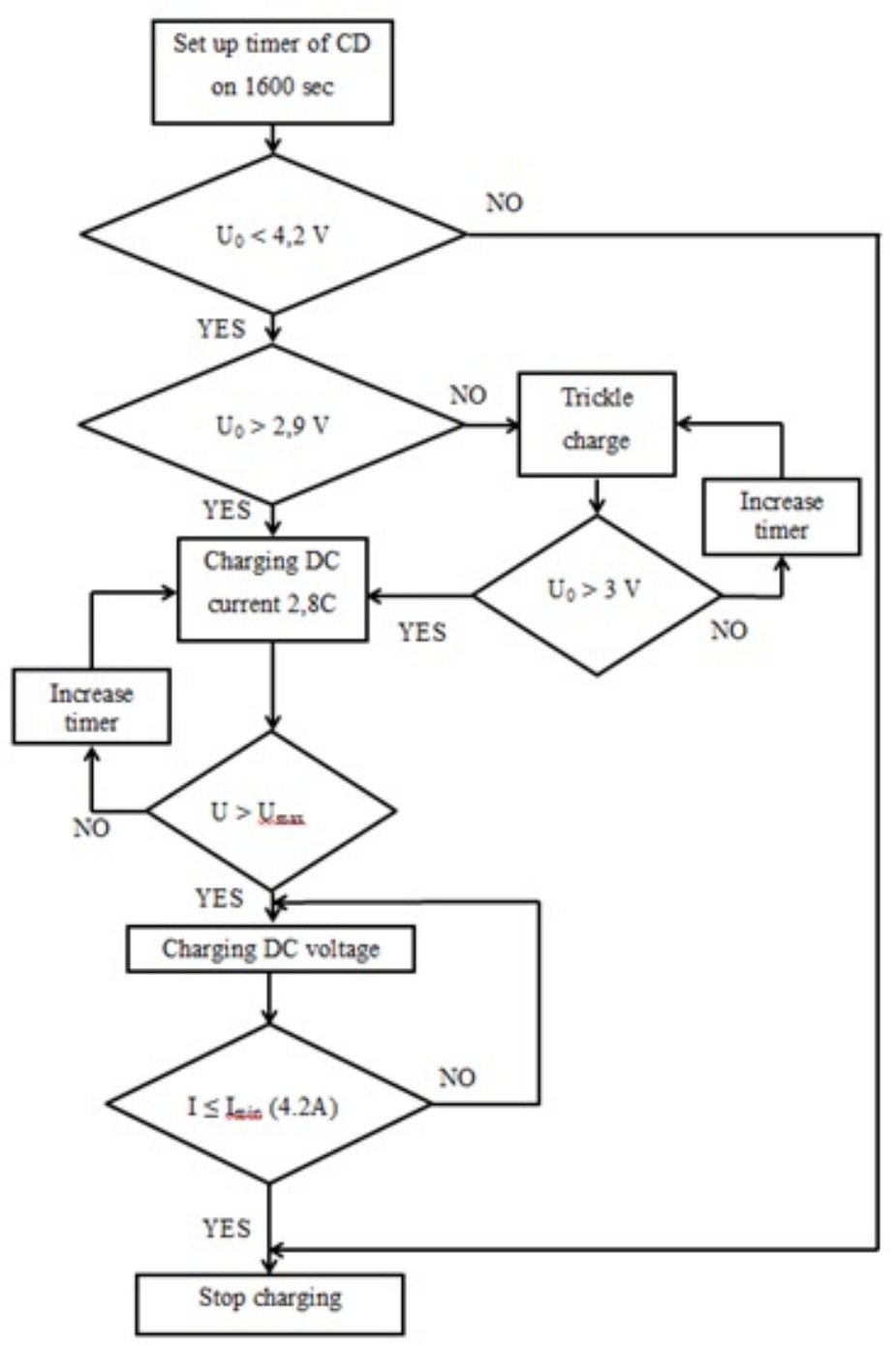

Fig. 3. Algorithm of Charging Device operation 
Since the one of the project indicators is the involvement of students into the Applied Scientific Research Experimental Works, we used Free Pascal, a shareware compiler of Pascal programming language, as a computer software for building the mathematic model of the battery. The main advantage of the shareware software is the legal base for its free usage and wide access to the study of documented source code for shareware programs for computers, and modify it including the building of own research on its base.

The results of modelling of discharge process are presented in Fig. 4. We showed the discharge curves of accumulating battery: one (solid) line is built on the base of calculation of mathematic model, and the other (dotted) line is built on the base of parameters of battery LT-LFP 300, while the discharge current Ip, temperature $+20^{\circ} \mathrm{C}$.

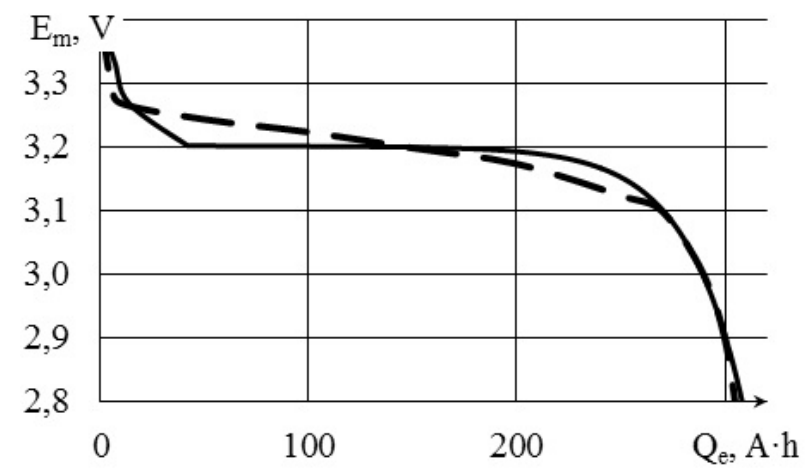

Fig. 4. Discharge curves of accumulating battery

\section{Conclusions}

The obtained dependences had leaded the following conclusion: the described mathematic model is adequate and could be used in the applied scientific research experimental works. During the modelling all tasks given to the scientists, were solved successfully.

This work was supported by Russian Federation Ministry of Education under Grant Subsidy Agreement 14.577.21.0154 of 28.11.2014 (Unique Agreement Code RFMEFI57714X0154).

\section{References}

1. GOST R EN 1986-2-2011. Cars with an Electric Traction. Measurement of an Energy Performance. Part 2. Hybrid Means of Transport. Moscow, Standartinform Publ., 2011. (in Russian)

2. Cars with an Electric and Hybrid Drive. Available at: http://www.antriebstechnik.com (accessed 5 May 2015).

3. Wu Jie, Wang Jia, Li Kun, Zhou Hau, Lv Qin, Shang Li, Sun Yihe. Large-Scale Energy Storage System Design and Optimization for Emerging Electric-Drive Vehicles. IEEE Transactions on Computer-Aided Design of Integrated Circuits and Systems, 2013, vol. 32, no. 3, pp. 325-338. DOI: 10.1109/TCAD.2012.2228268. 
4. Niederhausern A. [Storage Power Plant on Four Wheels]. Renewable Energy, 2009, no. 1, pp.21-22. (in German)

5. Yan Zheng-ping, Zhou Wei, Wang Wen-bin. [The Method of Predicting Modes of Gymnastics of Electromobiles]. Huadong Dianli East China Electric Power, 2013, vol. 41, no. 12, pp. 2567-2572. (in Chinese)

6. Presidential Decree "On Approval of the Priority Directions of Development of Science, Technology and Engineering in the Russian Federation and the List of Critical Technologies of the Russian Federation". Order of the President of the Russian Federation of April 17, 2003 No. Pr-655 on the Adjustment of the Priority Directions of Development of Science, Technology and Engineering in the Russian Federation and the List of Critical Technologies of the Russian Federation. (in Russian)

7. Jutt V.E. [Electric Equipment of Cars: a Textbook for High Schools]. Moscow, Goryachaya liniya - Telekom, 2006. (in Russian)

8. Tikhonov A.V. Improving the Efficiency of the Combined Systems of an Independent Electrical Supply Based on Renewable Energy Sources: Abstract of Thesis of Candidate of Technical Sciences: 05.14.08. Moscow, 2013. (in Russian)

9. Kirpichnikova I.M., Topol'skiy D.V., Topol'skaya I.G. [Relevance of Usage of the Freeware Soft in Modeling the Electric Engineering Systems Containg the Renewqbalke Energy Sources]. Aktualnyie Voprosyi Nauki: Materialy VII Mezhdunarodnoy Nauchno-Prakticheskoy Konferentsii [Actual questions of science: Proceedings of the VII International Scientific and Practical Conference]. Moscow, Sputnik, 2013, pp. 65-69. (in Russian)

Dmitry V. Topolsky, candidate of technical sciences, associate professor, department of electric engineering and renewable energy sources, South Ural State University, Chelyabinsk, Russian Federation, topol69@mail.ru.

Evgeny V. Solomin, doctor of technical sciences, professor, department of electric engineering and renewable energy sources, South Ural State University, Chelyabinsk, Russian Federation, evsolomin@inbox.ru.

Irina G. Topolskaya, senior Lector, department of electric engineering and renewable energy sources, South Ural State University, Chelyabinsk, Russian Federation, irina_topol'71@mail.ru.

Nikita Dmitrievich Topolsky, student, department of computers, South Ural State University, Chelyabinsk, Russian Federation, ntopolsky@mail.ru.

Received July 28, 2015 


\title{
МОДЕЛИРОВАНИЕ КОМПОНЕНТОВ ГИБРИДНОГО ГОРОДСКОГО И ПАССАЖИРСКОГО ТРАНСПОРТА В СВОБОДНО РАСПРОСТРАНЯЕМОМ ПРОГРАММНОМ ОБЕСПЕЧЕНИИ
}

\author{
Д.В. Тополъский, Е.В. Соломин, И.Г. Топольская, Н.Д. Топольский
}

\begin{abstract}
В рамках проекта «Разработка научно-технических решений компонентов мобильных зарядных устройств для аккумуляторных батарей гибридного и электрического приводов городского грузового и пассажирского автомобильного транспорт» группа ученых разработала математические модели литий-ионных аккумуляторных батарей $\mathrm{LiFePo} 4$ с целью изучения и проверки адекватности ранее разработанных алгоритмов заряда, для получения наиболее эффективного способа ускоренного заряда при сохранении качества батарей наряду с неизменным сроком их службы. Использование свободно распространяемого программного обеспечения существенно ускоряет работу, поскольку студенты и аспиранты могут использовать такой инструмент без всяких ограничений ввиду отсутствия лицензии. С учетом того, что литий-ионные батареи становятся сегодня все более востребованными во всем мире, данный научный сегмент заслуживает особого внимания. Проект нацелен на разработку системы ускоренного заряда, которая представляется экономически выгодной в плане применения в новых гибридных грузовых электромобилях КамАЗ, а тема является актуальной для разработки проектов по созданию специального зарядного оборудования для большегрузного и пассажирского транспорта, работающего от электротяги.

Ключевые слова: литий-ионная аккумуляторная батарея; городской транспорт; математическое моделирование; симуляция; свободно распространяемое программное обеспечение.
\end{abstract}

\section{Литература}

1. ГОСТ Р ЕН 1986-2-2011. Автомобили с электрической тягой. Измерение энергетических характеристик. Часть 2. Гибридные транспортные средства. - М.: Стандартинформ, 2011. - 20 c.

2. Автомобили с электро- и гибридным приводом. Risiken minimieren und Herausforderungen meistern // Mechatronik. - Sonderh: Antriebstechnik, 2013. C. $18-20$.

3. Wu, Jie. Large-Scale Energy Storage System Design and Optimization for Emerging Electric-Drive Vehicles / Wu Jie, Wang Jia, Li Kun, Zhou Hau, Lv Qin, Shang Li, Sun Yihe // IEEE Trans. Comput.-Aid. Des. Integr. Circuits and Syst. - 2013. - V. 32, № 3. - P. 325-338.

4. Niederhausern, A. Speicherkraftwerk auf vier Radern / A. Niederhausern // Erneuerbare Energ. - 2009. - № 1. - P. 21-22.

5. Yan, Zheng-ping. Метод прогнозирования режимов зарядки электромобилей / Yan Zheng-ping, Zhou Wei, Wng Wen-bin // Huadong Dianli East China Elec. Power. 2013. - T. 41, № 12. - P. 2567-2572. 
6. Указ Президента РФ «Об утверждении приоритетных направлений развития науки, технологий и техники в Российской Федерации и перечня критических технологий Российской Федерации» // Поручение Президента РФ от 17 апреля 2003 года № Пр-655 о корректировке приоритетных направлений развития науки, технологий и техники в Российской Федерации и перечня критических технологий Российской Федерации.

7. Ютт, В.Е. Электрооборудование автомобилей: учебник для вузов / В.Е. Ютт. 4-е изд., перераб. и доп. - М: Горячая линия - Телеком, 2006. - 440 с.

8. Тихонов, А.В. Повышение эффективности комбинированных систем автономного электроснабжения на основе возобновляемых источников энергии: автореф. дис. ... канд. тех. наук / А.В. Тихонов. - М., 2013. - 26 с.

9. Кирпичникова, И.М. Актуальность использования свободного программного обеспечения при моделировании электротехнических систем, содержащих возобновляемые источники энергии / И.М. Кирпичникова, Д.В. Топольский, И.Г. Топольская // Актуальные вопросы науки: Материалы VII Международной научнопрактической конференции. - М.: Спутник +, 2013. - С. 65-69.

Топольский Дмитрий Валерианович, кандидат технических наук, дочент, кафедра электротехники и возобновляемых источников энергии, Южно-Уральский государственный университет (г. Челябинск, Российская Федерачия), topol69@таil.ru.

Соломин Евгений Викторович, доктор технических наук, доцент, кафедра электротехники и возобновляемых источников энергии, Южно-Уральский государственный университет (е. Челябинск, Российская Федераиия), evsolomin@inbox.ru.

Топольская Ирина Геннадъевна, старший преподаватель, кафедра электротехники и возобновляемых источников энергии, Южно-Уральский государственный университет (ә. Челябинск, Российская Федерация), irina_topol71@mail.ru.

Топольский Никита Дмитриевич, студент, кафедра электронновычислительных машин, Южно-Уральский государственный университет (ә. Челябинск, Российская Федерация), ntopolsky@таil.ru.

Поступила в редакиию 28 июля 2015 г. 